\title{
Critical Notice: Catholicism and liberalism, R. Bruce Douglass and David Hollenbach, editors. Cambridge, Cambridge University Press: 1994. 352 pages.
}

\section{Ted Zenzinger}

Regis University

Catholicism and liberalism 1 a 1994 collection of essays edited by R. Bruce Douglass and David Hollenbach includes essays exploring three topics: missed opportunities for conversation between Catholicism and Liberalism2 before Vatican II, Catholic contributions to Liberalism, and Liberal contributions to Catholicism. Following a discussion of these topics, I conclude by suggesting points for future conversations.

\section{Missed Opportunities for Conversation before Vatican II}

One version of the confrontation between Catholicism and Liberalism tells the story of how Liberalism defended the rights and liberties of individuals in the face of a tyrannical and oppressive church; another version describes how the Church attempted to hold back the erosion of values and society in the face of individualism and materialism. A richer version of the confrontation is offered by Stenfel's "The failed encounter: The Catholic church and liberalism in the nineteenth century." Prior to 1864 , he notes, there was a missed opportunity for an exchange between Liberalism and Catholicism mediated by Catholic Liberalism. Although there were as many types of Catholic Liberals as styles of Liberalism, most Catholic Liberals appealed to individual religious freedom to defend Catholicism, opposed a full rejection of the French Revolution, accepted the idea that truth could be revealed through science, believed that scientific reason and theological reason should be used in appropriate areas, and attempted to minimize the influence of Liberalism on the structure of the Church itself. Because, however, Catholic Liberalism rejected the use of state power to impose Catholicism as the state religion, and because it was seen as encroaching on the papal monopoly on spiritual authority, the 
Church condemned Catholic Liberals for the heresy of indifferentism, labeled them as traitors, fools, pagans, diseased, and contended that they were the pawns of the devil. The central difficulty appears to have been the identification of Catholic Liberalism with the anticlerical and anti-religious ideology of Liberalism. Had the Church instead recognized that Catholic Liberalism was not a complete endorsement of Liberalism, Catholic Liberalism might have served as a mediator.

The encounter between Liberalism and Catholicism was initially much less virulent in the United States, as Gleason recounts in "American Catholics and liberalism, 1789-1960." Gleason begins by noting that Americans drew a distinction between Ecumenical and Sectarian Liberalism: the former endorsed individual rights, liberties, and freedoms, the restriction of state power, and representative government while the latter added to these anti-clericalism and an opposition to religion. When Ecumenical Liberalism was dominant in America there was fertile ground for the development and support of Catholic Liberalism, particularly in light of the American separation of spiritual and political realms, each of which was to be governed by the appropriate authority, and in light of the important fact that despite the separation, America was a religious nation. After 1844, however, changes in America and Europe ensured that no conversation mediated by Catholic Liberalism would occur. In America, fears of Catholic growth, the rise of evangelical groups opposed to Catholicism, and concern that the hierarchy of the Church made Catholicism incompatible with democracy worked to transform Liberalism from Ecumenical to Sectarian. In Europe, the papacy opposed the use of state power to resolve social problems (e.g. the New Deal), attacked modernism, renewed calls for Catholicism to become the state religion, and allied itself with antidemocratic fascist governments. Thus, another opportunity for an exchange between Liberalism and Catholicism was lost.

The value of these essays is that they enrich the history of the interaction between Liberalism and Catholicism. In keeping with this, a discussion of this history from the perspective of Liberal historians would be useful, for it would most probably included discussions of the Inquisition, Witch-Hunts, and Holocaust; events 
that have contributed to the conversation between Catholics and Liberals. Second, although the focus of these essays is historical, a welcome inclusion would be a discussion of the Church's response to Liberation Theology, for here, too, it seems that the Church has failed to note the differences between Liberation Theology and Communism, and has thus lost an important opportunity for a conversation with Communism mediated by Liberation Theology.

\section{Catholic Contributions to Liberalism}

As Komonchak argues in "Vatican II and the encounter between Catholicism and liberalism" Vatican II was not simply, despite beliefs to the contrary, a wholesale endorsement of Liberalism. While the Church did accept the separation of church and state, renounced calls for the use of state force to impose Catholicism as the state religion, and accepted the right to religious freedom, it did so, not by embracing atomistic individualism, but by acknowledging the role this separation and this right (among others) played in the life of the community. As Hollenbach explains in "A communitarian reconstruction of human rights: contributions from Catholic tradition" the Church rejected the Liberal conception of the individual as a self established prior to and independently of relationships, whose freedom consists in setting both its own goals and determining its own individual conception of the good, whose rights are a protection from the encroachment of the state and other individuals, and who demonstrates autonomy by casting aside external restraints. Instead, the Church embraced a vision of the self as social, as interconnected; as a self whose rights are not protections, but the minimum conditions for participating in the life of the community. Thus, the Church endorses the right to free speech and religious freedom, not because these rights protect the freedom of the individual to say and believe what she chooses, but because "Ip]eople should be free to express their political and religious beliefs in public in order that the true nature of the common good of the community might be more adequately understood and pursued." 3 Hollenbach even suggests that the right not to be tortured is communal in nature, for torture violates the right to be treated as a member of the community. Thus, while the Church 
might support some of the same rights and freedoms as Liberalism, it does so for different reasons, and thus Vatican II is not simply an endorsement of Liberalism. What Vatican II and the majority of the essays in Catholicism and liberalism do begin is a constructive critique of Liberalism.

Elshtain, drawing inspiration from Tocqueville and Aristotle, argues in "Catholic social thought, the city, and liberal America" that individualism has led to the pursuit of individual rather than shared ends with a consequent decrease in support for the organizations that make up civil society. This is evidenced by increased murders and out-of-wedlock pregnancies. The decline of civil society has allowed the state to step in, with the result that we are well on the way to Tocqueville's predicted tyranny of the state. This would be bad in itself, but Elshtain contends that the state is not well placed to resolve the social problems traditionally dealt with by civil society; for example, those facing the family. Therefore, drawing inspiration from Aristotle, Elshtain calls for a renewed civil society, starting with a change in the political and legal structures to give more power and autonomy to cities, which not only help resist the tyranny of the state, but are well placed to nurture civil society. Such cities will incorporate a shared view of the common good, promote rights and responsibilities, and produce "chastened patriots"-individuals who are skeptical about nationalism, but support local civic activity.

Gellott develops Elshtain's critique by examining the impact of Liberalism on a key aspect of civil society: the family. In "The family, liberalism, and Catholic social teaching" Gellott argues that Liberalism has relegated the family to the private sphere and is thus forced into silence on the problems it faces. Additionally, the individualism of Liberalism has reduced family relationships to contractual relationships. Third, Liberalism has promoted materialism, which has further eroded the family by requiring all of the efforts of the family to be focused on the acquisition of goods, rather than the promotion of the family itself. Finally, Liberalism has allowed each individual to define the family as s/he chooses, further eroding the function and role of the family. Thus, Liberalism has both left the family to fend for itself, and has introduced 
forces hostile to the family. Drawing upon a Catholic vocabulary, Gellott attempts to repair the damage done by Liberalism.

First, Catholic social thought offers the concept of mediating institutions (Elshtain's civil society). Thus, the family need not be regulated to the private (or public spheres). Second, Catholic discussion of solidarity offers an alternative to the contractual vision of the family (and society), for it views rights as both freedoms and obligations. In addition, solidarity offers a critique of materialism and suggests that the focus of the family need not be the acquisition of goods. Finally, Catholicism offers a child-focused definition of the family. Recognizing the narrowness of this definition, Gellott attempts to soften its impact by suggesting that a richer definition of friendship be developed.

Gellott's adoption of the vocabulary of Catholic social thought is not un-critical: she notes that Catholic social thought places the onus on women to be the nurturers, holds a negative attitude toward women who work outside of the home, and denies women equality by denying them ordination. Before we examine these concerns, I want to examine another criticism of Liberalism.

Drawing on a historical discussion of the common good, Dupre in "The common good and the open society" contrasts the view of the common good in the Catholic tradition (Augustine and Aquinas) with that of the modern, Liberal tradition (Hobbes and Locke). While the Catholic tradition contains a disagreement as to the nature of the common good, immanent or transcendent, the Liberal tradition faces a more intractable problem. Incorporating a neutrality toward individual conceptions of the good, and thus endorsing no conception of the common good, it lacks an objective standpoint from which to adjudicate disputes among individuals. Dupre therefore proposes a return to the Catholic common good tradition, which offers an objective common good, and "...a religiousmoral view of the human place in the cosmos and society." $4 \mathrm{He}$ adds, "[w]hat I am defending, in plain terms, is a return to virtue on a religious basis as an indispensable condition for any possibility of a genuine conception of, and respect, for the common good."'s It is interesting to note that of the authors in the volume only Dupre speaks specifically of a religious understanding of the common good. 
A related problem is discussed by Tracy in "Catholic classics in American liberal culture": without a shared common good there is no shared vocabulary, save that of the restrictive instrumental reason, with which to hold public debates. This leads Tracy to ask how Catholic social thinkers can present their ideas without employing a Catholic or shared vocabulary. The solution is ingenious. Tracy reminds us that while "...every classic work of art or religion is highly particular in both origin and expression [it is]...deeply public in effect."6 Thus a Catholic could present her/his position not by means of an argument rooted in Catholicism or instrumental reason, but by selecting classic works of art and literature, offering them to the public as the basis for a civic discourse, and thereby bringing about a public conversation in which the truth may be revealed. Tracy reminds us that he is drawing here upon the second of two American traditions: the Puritan Covenantal Conversation tradition.

\section{Liberal Contributions to Catholicism}

As I noted earlier, Gellott raises important Liberal criticisms of Catholicism: the onus on women to be the nurturers, negative attitudes toward women who work, and the denial of equality demonstrated by restricting ordination to men. Drawing from Liberal Feminism, Segers raises similar concerns in "Feminism, liberalism, and Catholicism." She notes first that the Church holds the view that women are by nature best suited to be mothers and nurturers, and thus should make these their primary tasks. Second, that by denying ordination to women the Church reveals that it does not consider women to be equal to men. And, third, that the Church reveals its prejudice against women by selecting from the varied symbolism employed in the sacred writings only those that disempower women. For example, using only male terminology to refer to God and thereby ignoring the instances of female and neutral references to God.

Despite these important criticisms, Segers believes that there are important commonalities that will foster a conversation between Catholicism and some varieties of Feminism. Although the reasoning employed differs significantly, Catholics and some Femi- 
nists seek to ban pornography, seek to ban contract pregnancy, and seek to offer alternatives to abortion.

\section{Future Conversation}

In this final section I want to raise three topics for further conversation between Liberalism and Catholicism: the relationship between the individual and the common good, the content of the common good, and the resources available to Liberalism to address the important challenges raised in Catholicism and liberalism.

As a starting point, consider the following: "It suffices that we agree on the principle that the good of the community takes precedence over the maximum fulfillment of the individual, and that we be prepared to accept this as a maxim for moral action." 7 It is not immediately evident what Dupre means here by "maximum fulfillment of the individual", but what is evident is that the individual good will, in at least some circumstances, but subordinate to the common good. This passage gives rise to two concerns for Liberals: first, it seems to leave the individual without protectionat any time the good of the individual may be sacrificed for the common good; second, since Dupre's understanding of the common good is a religious one, and more particularly, a Catholic one, not only is the individual good subordinate to a Catholic common good, but given the key role envisioned for the common good, a Catholic understanding of the common good would seem to lead to the development of a Catholic society.

Elshtain attempts to address the first concern through the doctrine of subsidiarity: “...it is an injustice and at the same time a grave evil and disturbance of right order to assign to a greater and higher association what lesser and subordinate organizations can do. For every social activity ought of its very nature to furnish help (subsidium) to the members of the body social, and never destroy and absorb them." Following Komonchak, she understands the doctrine of subsidiarity to offer protection to the individual good, for to make the individual good simply subservient to the common good would be to deny individuals the right to exercise self-responsibility, and society is not to supplant this right but to augment 
it.' It remains to be determined whether this reading of subsidiarity offers sufficient protection to the individual good.

That it might not is suggested by Ex Corde Ecclesiae.10 Here the Church clearly affirms that the common good outweighs both freedom of academic inquiry and possibly even freedom of speech. Consider just two passages:

"The Church, accepting the legitimate autonomy of human culture and especially of the sciences', recognizes the academic freedom of scholars in each discipline in accordance with its own principles and proper methods, and within the confines of the truth and the common good."11 [emphasis added] [It should be noted here that "truth" and "common good" are determined by the Church.]

and,

"It is intrinsic to the principles and methods of their research and teaching in their academic discipline that theologians respect the authority of the bishops, and assent to Catholic doctrine according to the degree of authority with which it is taught."12 [emphasis added]

There are many other similar passages, but these two serve, I think, to indicate the limited degree to which the Church is willing to protect the good of the individual: even freedom of speech and research are subservient to the dictates of the (Catholic) common good. Further evidence is offered by Provost's "Rights of persons in the church" where, using the right to baptism as an example, he describes the difficulties that arose when disputes occurred: not only was there no clear process of adjudication, but the process that existed allowed parties to the dispute to participate in its settlement. Thus, individuals have to worry that their individual good is not protected from the intrusion of the common good and that they 
may have limited means, depending upon jurisdiction, to redress unwarranted intrusions.

The central difficulty with using subsidiarity to protect the individual good, then, is that the individual's right to exercise selfresponsibility stems from the common good; having no independent support, the right exists at the whim of the common good (similarly the right to baptism has no independent support; existing only at the whim of the Church). The difficulty I have in mind is similar to one often raised against utilitarianism: within utilitarianism individuals have rights, but these rights are simply privileges it is to the advantage of the greatest happiness of the greatest number for individuals to hold. Thus, freedom of speech, for example, may be revoked or restricted should the possession of this freedom by individuals no longer promote the greatest happiness of the greatest number.13 Similarly, should circumstances change, should "right order" require it, the right to exercise self-responsibility may be revoked.

These selections from Ex Corde Ecclesiae also suggest some important questions about the relationship of civil society to private and public society. If the institutions involved are private, then it might not seem out of place that the Church, by imposing restrictions on the membership and activities of the faculty, attempt to preserve the Catholic character of the institutions. If, on the other hand, the institutions involved are viewed as public, then the restrictions imposed by the Church seem to be out of keeping with the protections afforded by the Constitution and Bill of Rights. What, however, if the institutions are viewed as part of civil society, as part of that society that exists "between" private and public? Should the rules of the Church State take precedence? Since the institutions have both a religious heritage and receive state support (in the form of financial aid to students, at least), the rules of both the Church and State can claim jurisdiction. What is required, then, is a conversation about jurisdiction, and the role of the State and Church in civil society.

Dupre's passages also raises the problem of determining the content of the common good, and the related concern that if the content is Catholic, one is in principle endorsing a Catholic society. Dupre suggests that the "...citizens build the common good up 
from the ground...constantly revising and reconceiving it in accordance with the particular needs of the time....The common good ought to reflect the ever-active choices of free individuals, which it grounds, guides, and restricts."14 Most would agree, I think, that the common good ought to be a reflection of the view of the individuals who constitute the society; however, Dupre offers no clear procedure for the construction of interpersonal utility scales, and no resolution to the problems that attend such a construction. For example, Arrow's contention that there is no way to translate individual preferences into a social preference without violating the condition of nondictatorship. 15 Lastly, Dupre needs to reconcile this passage with the one cited earlier in which he calls for a religious content for the common good: there is no guarantee that the common good constructed from the preferences of individuals in the society will be a common good with religious content. Possibly these problems can be solved, but more worrisome is Dupre's call for a religious understanding of the common good.

When Dupre calls for a religious understanding of the common good and "...a religious-moral view of the human place in the cosmos and society" 16 what is entailed? A view of the universe as the place of a cosmic struggle between good and evil? A conception of sin and salvation? One could add to this list of questions indefinitely, but the worry expressed is that Catholicism, thwarted in its overt attempt to make itself the state religion, instead seeks to achieve the same result by means of endorsing a common good, and then ensuring that the common good endorsed is Catholic in character. This worry is somewhat far fetched, but raising it leads to several important issues. First, how is the content of the common good to be determined? Is it to be specified, and if so by whom? Is it to be constructed, and if so by what process? Second, since there are different understandings of the content of the common good, what will the relationship of these contents be to one another? One might not agree with Dupre that the content of the common good must be religious, but the implicit question is important: what should be the content of the common good?

The essays in Catholicism and liberalism have raised some important difficulties for Liberalism, and in so doing have contributed to an important conversation. I next want to examine some 
possible beginnings of a Liberal contribution to this conversation. Specifically, I want to examine Catholic assumptions about the Liberal conception of the person, the options Liberals have for resolving disputes among individuals, Liberal contributions to public reason, and Liberal responses to the problems facing the family. In order to fix ideas, I will use John Rawls's Political Liberalism 17 as the basis for the Liberal contributions to this conversation.

One of the key assumptions of the essays is that Liberalism's conception of the person is one of individuals defined prior to social unions, and of individuals who are engaged in a process of self-invention that necessitates violating any and all established social rules. The second, part of what Elshtain labels "ultra-liberalism", is true, perhaps of Nietzsche's or Foucault's conception of the individual, but it is not immediately evident that it holds true for all or even most Liberalisms. Moreover, it is not immediately evident that Liberalism must embrace both of these features. That Liberals, too, might hold a conception of the person that is socially determined, even if defined prior to social unions, is exemplified by Rawls' political conception of the person as possessing two moral powers: the capacity for a conception of the good and the capacity for a sense of justice, each of which requires for development and exercise the basic liberties, several of which, including freedom of association, are social.

In his essay, Dupre suggests that lacking a conception of the common good and being neutral with respect to the good of individuals, Liberalism has no objective standpoint from which to adjudicate disputes among individual conceptions of the good. What is not evident is that Liberalism needs an objective standpoint, and that lacking one, it has no means for adjudicating disputes. Again, consider the Liberalism of John Rawls. Rawls argues that individuals behind the veil of ignorance will construct the two principles of justice, which will then be used to guide the constitutional convention, and later legislative and judicial decisions. While the two principles of justice are not "objective" in the sense meant by Dupre, they do serve to adjudicate disputes among individuals, and since they are constructed by representative individuals using ideas latent in Anglo-American democratic society, they possess, Rawls contends, the needed authority. 
Tracy raises and ingeniously resolves another problem for Liberalism: since Liberalism lacks a conception of the common good, it lacks a common vocabulary, save for that of instrumental reason, and thus offers no vocabulary for Catholic social thinkers to articulate their views. First, it might be interesting to explore how far one could take instrumental reason; consider for example Gauthier's Morals By Agreement ${ }^{18}$ where using only the vocabulary of decision theory he argues for such basic moral principles as the need to keep promises. Second, it is not immediately evident that if there is a conception of the common good that Catholic social thinkers will be in a better position-it is always possible that the conception of the common good is antithetical to Catholicism and thus offers it no vocabulary with which to articulate its positions. Finally, Tracy has offered an ingenious solution, the employment of classic works to initiate conversation, but Rawls, too, has a solution worth considering. Rawls suggests that when involved in public discussions of justice individuals are allowed to employ the vocabulary of their individual, private, conceptions of the good, so long as at a later time, they demonstrate how their positions may be defended by using public reason, e.g. by using the common vocabulary of public documents such as the Constitution, Bill of Rights, Supreme Court Opinions, et cetera. While there is a significant limitation here, the need to at some point demonstrate that the private view can be supported by public reason, there is at least an option available for Catholic social thinkers.

Lastly, Gellott raises important concerns stemming from Liberalism's treatment of the family as private, which has the result that the family can not be given the support it requires. Placing the family within civic society can, she contends, offer it the required support. It is worth noting that Liberalism has an additional option: treat the family as a public institution and thereby offers its members the protection afforded by public law.19 This suggestion again opens a conversation about the relationship of public society to civil society, and the ability of each to protect and nurture institutions.

I have not sought here to develop and argue for Liberalism; my purpose was only to suggest some possible points to encourage future conversations. If we are, as Rawls contends, in an age where the traditional liberal compromise establishing public and private realms and assigning religion to the private realm is unraveling, 
then such conversations as those suggested by Catholicism and liberalism will be critical if we are avoid a contemporary version of the 17th Century Wars of Religion.

\section{Notes}

1. Douglass, R. Bruce, and Hollenbach, David, eds. Catholicism and liberalism. Cambridge: Cambridge University Press, 1994.

2. For parity, I have changed the convention followed in $\mathrm{Ca}$ tholicism and liberalism of capitalizing "Catholicism" but not "liberalism."

3. Catholicism and liberalism, p. 142.

4. Ibid, p. 189.

5. Ibid, p. 189.

6. Ibid, p. 203.

7. Ibid. p. 188.

8. "Quaragesimo Anno", Number 74, quoted in Catholicism and liberalism, p. 161.

9. Catholicism and liberalism, p. 161.

10. "Ex Corde Ecclesiae" reprinted in Langan, S.J., John P., ed. Catholic Universities in Church and Society: A Dialogue on Ex Corde Ecclesiae. Washington: Georgetown University Press, 1993.

11. Ibid, pp. 238-239.

12. Ibid, p. 239.

13. For a clear presentation of this problem as it pertains to act and rule utilitarianism see Martin, Rex. A System of Rights. Oxford: Oxford University Press, 1993.

14. Catholicism and liberalism, op. cit., p. 191.

15. For a discussion of these problems, including Arrow's Impossibility Theorem, see Resnik, Michael D., Choices. Minneapolis: University of Minnesota Press, 1987. See also Strasnick, Steven. "The Problem of Social Choice: Arrow to Rawls." Philosophy and Public Affairs, 5.3 (1976): 241-273.

16. Catholicism and liberalism, op. cit., p. 191.

17. Rawls, John. Political Liberalism. New York: Columbia University Press, 1996.

18. Gauthier, David. Morals by Agreement. Oxford: Oxford University Press, 1986. 
19. See, for example, Okin, Susan. Justice, Gender; and the Family. New York: Basic Books, 1989. In this work, she argues, contra Rawls, that the family should be regarded as a public institution, and that its members should be held to standards of justice similar to those required of citizens. 